\title{
Perception on Bank Interest and The Use of Islamic Banks: Case study Indonesian Students in Medina Saudi Arabia
}

\author{
Ahmad Bilal Almagribi ${ }^{1}$ \\ State Islamic Institute of Palangka Raya, Indonesia \\ abalmagribi@gmail.com \\ Bayu Taufiq Possumah ${ }^{2}$ \\ Universiti Malaysia Terengganu, Malaysia \\ bayu@umt.edu.my \\ Halimi Husayn ${ }^{3}$ \\ Islamic University of Medina, Saudi Arabia \\ 381007746@stu.iu.edu.sa
}

\begin{abstract}
This study aims to investigate the perceptions of Indonesian students in Medina, the Kingdom of Saudi Arabia about bank interest and Islamic banks usage. By using questionnaires data collection method and purposive sampling technique, 40 students have been interviewed online in this study. The data is then analyzed by descriptive percentage. This study found that most Indonesian students in Medina consider bank interest as usury and only $5 \%$ of them thought that both were different. The students who consider bank interest as usury argue that the contract between the customer and the bank is a Qordh (loan) contract. In contrast, respondents who consider the bank interest and usury are different, arguing that the interest is not always as usury according to some scholars who do not categorize the contract between bank and customer as Qordh, but as Tamwil (financing). This study also found that most of the students using Islamic banks and at the same time some of them also have conventional accounts for various reasons, such as the limited number of ATMs and branch offices, and no Islamic debit cards yet that are accepted as credit cards in online transactions.

Keywords: Perception, Bank Interest, Islamic Banks, Indonesian Students, Medina
\end{abstract}




\section{INTRODUCTION}

Although the Indonesian Ulama Council (MUI) since 2004 has declared the illegal interest rate of banks, ${ }^{1}$ followed by similar fatwa by the Assembly of Tarjih and Tajdid Muhammadiyah Central Leadership in 2006, ${ }^{2}$ some Indonesian citizens still use conventional banks to save their assets with various reasons. The loyality of Islamic bank users are still going unexpected. Some later criticize that Islamic banks is similar to conventional banks.

Afandi and Ernawati have conducted qualitative research on the source of funds and perceptions about bank interest by taking Muslim traders in Pasar Basah Mandonga in Kendari City as research subjects. ${ }^{3}$ Meanwhile, Rahmawaty has conducted quantitative research on the influence of Islamic bank perception on the interest of using BNI Syariah products in Semarang City. ${ }^{4}$ So far, the author's search has not found any studies on the perceptions of bank interest or use of Islamic banks from Indonesian citizens living abroad. Therefore, the authors are interested in researching the perception of bank interest and the use of Islamic banks from Indonesian students studying in Medina. The city is one of the holy lands for Muslims other than Mecca.

The aim is to know the perception of Indonesian students about bank interest, as educated people living and studying in the Kingdom of Saudi Arabia, a country is known for applying Islamic Laws. Then to find out also their perception of Islamic banks in Indonesia, whether they are also Islamic bank customers or not. As well as the reasons for the use and lack of Islamic banks compared to conventional banks as a material for evaporation and improvement of Islamic banks in the future.

\section{RESEARCH METHODS}

This study used primary data collection method in the form of questionnaires and online interviews with descriptive analysis approach. The research population is 40 students that representing as Islamic bank users as well as conventional bank users who were selected by purposive sampling with male criteria, in the millennial age (22-30 years), active students or alumni of one of the universities in Medina with a maximum of graduation in 2019

\section{FINDINGS AND DISCUSSIONS}

\section{Demographic Description of Respondents}

Demographics of respondents based on the gender of 40 men (100\%). The demographics of respondents based on age are as follows:

\footnotetext{
1 '32.-Bunga-InterestFaidah.Pdf', accessed 22 December 2020, http://mui.or.id/wpcontent/uploads/files/fatwa/32.-Bunga-InterestFaidah.pdf.

2 'Fatwa 08-2006_Bunga Bank.Pdf', accessed 22 December 2020, http://tarjih.muhammadiyah.or.id/muhfile/tarjih/download/Fatwa\%2008-2006_Bunga\%20Bank.pdf.

${ }^{3}$ Nur Afandi and Ernawati Ernawati, 'Sumber Dana Dan Persepsi Tentang Bunga Bank Oleh Pedagang Muslim (Studi Pedagang Di Pasar Basah Di Kota Kendari Tahun 2015)’, Muqtasid: Jurnal Ekonomi Dan Perbankan Syariah 9, no. 1 (26 June 2018): 70-81, https://doi.org/10.18326/muqtasid.v9i1.70-81.

${ }^{4}$ Anita Rahmawaty, 'Pengaruh Persepsi Tentang Bank Syariah Terhadap Minat Menggunakan Produk di BNI Syariah Semarang’, ADDIN 8, no. 1 (15 November 2015), https://doi.org/10.21043/addin.v8i1.587.
} 
Ahmad Bilal Almagribi, Bayu Taufiq Possumah, Halimi Husayn

Table 1.1 Age of Respondents

\begin{tabular}{|c|c|c|}
\hline Age & Number of Respondents & Percentage \\
\hline 22 years old & 3 people & $7,5 \%$ \\
\hline 23 years old & 5 people & $12,5 \%$ \\
\hline 24 years old & 3 people & $7,5 \%$ \\
\hline 25 years old & 11 people & $27,5 \%$ \\
\hline 26 years old & 9 people & $22,5 \%$ \\
\hline 27 years old & 3 people & $7,5 \%$ \\
\hline 28 years old & 4 people & $10 \%$ \\
\hline 29 years old & 1 person & $2,5 \%$ \\
\hline 30 years old & 1 person & $2,5 \%$ \\
\hline Total & $\mathbf{4 0}$ people & $\mathbf{1 0 0} \%$ \\
\hline
\end{tabular}

From the table 1.1, all respondents fall into the millennial age category because they were born between 1980 and 2000. ${ }^{5}$ The majority of respondents were 25 years old as many as 11 people (27.5\%) and 26 years as many as 9 people (22.5\%).

Table 1.2 Student Status of Respondents in Medina

\begin{tabular}{|c|c|c|}
\hline Status & Number of Respondents & Percentage \\
\hline Active Students & 19 people & $47,5 \%$ \\
\hline Alumni 2020 & 6 people & $15 \%$ \\
\hline Alumni 2019 & 15 people & $37,5 \%$ \\
\hline Total & $\mathbf{4 0}$ people & $\mathbf{1 0 0 \%}$ \\
\hline
\end{tabular}

Most respondents are active students in Medina with a total of 19 people (47.5\%), then alumni students in 2019 amounted to 15 people (37.5\%), and alumni students in 2020 as many as 6 people (15\%).

Table 1.3 Alma mater of Respondents' Study Place in Medina

\begin{tabular}{|c|c|c|}
\hline Almamater & $\begin{array}{c}\text { Number of } \\
\text { Respondents }\end{array}$ & Percentage \\
\hline Islamic University of Medina & 37 people & $92,5 \%$ \\
\hline Taibah University & 3 people & $7,5 \%$ \\
\hline Total & $\mathbf{4 0}$ people & $\mathbf{1 0 0 \%}$ \\
\hline
\end{tabular}

Most respondents are the Almamater of the Islamic University of Medina with a total of 37 people (92.5\%) and the rest of Taibah University as many as 3 people $(7.5 \%)$.

\footnotetext{
${ }^{5}$ Neila Susanti and Marliyah Marliyah, 'Pola Pemberdayaan Ekonomi Generasi Milenial Komunitas Serikat Saudagar Nusantara (SSN)', Lainnya (Medan: LP2M UIN Sumatera Utara Medan, October 2018), http://repository.uinsu.ac.id/5102/.
} 
Ahmad Bilal Almagribi, Bayu Taufiq Possumah, Halimi Husayn

Table 1.4 Education That Respondents Are Currently/Were Experiencing in Medina

\begin{tabular}{|c|c|c|}
\hline $\begin{array}{c}\text { Last/Current Education in } \\
\text { Medina }\end{array}$ & $\begin{array}{c}\text { Number of } \\
\text { Respondents }\end{array}$ & Percentage \\
\hline I'dad (Getting Started) & 0 people & $0 \%$ \\
\hline Bachelor & 30 people & $75 \%$ \\
\hline High Diploma & 4 people & $10 \%$ \\
\hline Master & 6 people & $15 \%$ \\
\hline Doctor & 0 people & $0 \%$ \\
\hline Total & $\mathbf{4 0}$ people & $\mathbf{1 0 0} \%$ \\
\hline
\end{tabular}

Many respondents are active students or bachelor graduates in Medina with a total of 30 people (75\%), then active students master 6 people (15\%), and high diplomas as many as 4 people (10\%). Language preparation (i'dad) students and doctors were not included in the respondents to this study.

\section{Perceptions About Bank Interest}

The first question asked to respondents was how they perceived the bank interest in conventional banks, whether it is same as usury that forbidden in Islam or different. The respondents' answers and percentages are shown in table 2.1 as follow:

Table 2.1 Is Bank Interest Equal to Riba

\begin{tabular}{|c|c|c|}
\hline Respondent's Perception & Number of Respondents & Percentage \\
\hline Yes & 38 people & $95 \%$ \\
\hline Not & 2 people & $5 \%$ \\
\hline Total & $\mathbf{4 0}$ people & $\mathbf{1 0 0 \%}$ \\
\hline
\end{tabular}

Majority of respondents with a total of 38 people (95\%) states that the existing interest in conventional banks is the same as riba. While 2 others (5\%) states that bank interest is not same as usury. This result is in line with research finding conducted by Putra at the College of Economics Indonesian Banking School ${ }^{6}$ and the State Islamic Institute of Purwokerto where the majority of students also agreed that bank interest is the same as riba. ${ }^{7}$

Similarly, Veronica's research stated that the fatwa against bank interest issued by MUI has an effect of $60.6 \%$ on the interest of Tasikmalaya Islamic College students to be Islamic bank customers. ${ }^{8}$ This study emphasizhed by Irwanti's research on students from 4 campuses in Serang; Sultan Maulana Hasanuddin State Islamic University Banten, Ageng Tirtaysa University, Bina Bangsa University, and Serang Raya University that showed the motivation to avoid usury influenced students' decision to become Islamic bank customers

\footnotetext{
${ }^{6}$ Rizky Dwi Putra, 'Analisis Pengaruh Pengetahuan Riba Dan Sikap Kepada Bank Syariah Terhadap Intensi Menjadi Nasabah Bank Syariah (Studi Kasus Pada Mahasiswa STIE Indonesia Banking School)’ (diploma, STIE Indonesia Banking School, http://lib.ibs.ac.id/index.php?p=show_detail\&id=4457\&keywords=RIZKY+DWIPUTRA.

7 Permata Hati Kilau, 'Pengaruh Pemahaman Mahasiswa Perbankan Syariah Atas Bunga Dan Bagi Hasil Terhadap Minat Menjadi Nasabah Bank Syariah (Studi Kasus Mahasiswa Perbankan Syariah IAIN Purwokerto Angkatan 2016-2019)' (skripsi, IAIN Purwokerto, 2020), http://repository.iainpurwokerto.ac.id/8649/.

${ }^{8}$ Vera Veronica, 'Pengaruh Fatwa Majelis Ulama Indonesia (MUI) Tentang Bunga Bank Terhadap Motivasi Mahasiswa Program Studi Ekonomi Syariah Di Stai Tasikmalaya Menjadi Nasabah Bank Syariah’ (diploma, STAI Tasikmalaya, 2018), http://repository.staitasik.ac.id:86/25/.
} 
by 59\%. ${ }^{9}$ On the contrary, Syam's research shows that students' understanding of The State Islamic Institute of Parepare about usury does not affect customers' interest in saving in conventional banks. ${ }^{10}$

\section{Why Bank Interest Are the Same or Different from Usury}

Most respondents in this study stated that conventional bank interest is same as riba, they mentioned the following reasons: (i) The agreement between the bank and the customer, both as a depositor and a borrower is considered to use the Qordh agreement (loan). (ii) Additional fees paid by the customer as a borrower to the bank are usury. (iii) The additional balance in the form of interest given by the bank for the customer as a depositor with the Qordh agreement is usury. (iv) The rule of "Any benefits from loan is usury". (v) The additional balance value given to the customer as a depositor does not refer to the value of real business profit carried out by the bank with the customer's money, but rather refers to the interest rate. (vi) The origin of bank interest for depositor is unclear, hence it is primarily abandoned. (vii) The term savings or deposit to the bank does not change the status of Qordh contract. (viii) The rule of العبرة في العقود للمقاصد و المعاني لا للألفاظ و المباني (The benchmark in the contract is its purpose and substance, not its text and plot).

As for the respondents who stated that bank interest is different from riba, they refer to: (i) The opinion of Majma Buhuts Al-Islamiyyah, a fatwa institution in Egypt states that the contract between the customer and the bank is not a Qordh agreement despite similarities, but rather a Tamwil (financing) agreement. (ii) Individual receivables (prophet's time) and collective receivables (banks) are different. (iii) Not all bank interest is usury, for example, the interest that given when the customers saves their money in the bank. Unlike the interest charged when customer owes to the bank.

Some respondents who said bank interest is riba refers to fuqaha with a textual paradigm that understands the ilat of riba prohibition lies in the existence of additional, as is the linguistic meaning of the word riba itself and based on the confirmation of the Qur'an that only the principal of capital can be taken. Hence, if the ilat is in the bank interest, then it is riba. ${ }^{11}$ The amount of interest that must be paid by the borrower depends on the nominal credit received, not depending on his/her business income. ${ }^{12}$ The scholars have agreed that usury is prohibited, but there is no scholars agreement regarding bank interest is usury. As said by Shaykh Ali Jum'ah, one of reknown Egyptian scholars. ${ }^{13}$

\footnotetext{
${ }^{9}$ Mayang Irwanti, 'Pengaruh Motivasi Menghindari Riba Terhadap Keputusan Menjadi Nasabah Bank Syariah (Studi Kasus Mahasiswa di Fakultas Ekonomi UIN SMH Banten, UNTIRTA, UNIBA, UNSERA)’ (diploma, UIN SMH BANTEN, 2020), http://repository.uinbanten.ac.id/5108/.

${ }^{10}$ Anggeryani Syam, 'Pengaruh Pemahaman Riba Terhadap Minat Menabung Di Bank Konvensional (Studi Mahasiswa Prodi Perbankan Syariah IAIN Parepare' (undergraduate, IAIN Parepare, 2019), http://repository.iainpare.ac.id/627/.

${ }^{11}$ Rahmat Firdaus, 'Perbedaan Pandangan Fuqaha Ihwal Bunga Bank Dan Riba', EKONOMIKA SYARIAH : Journal of Economic Studies 3, no. 2 (17 December 2019): 47-60, https://doi.org/10.30983/es.v3i2.2150.

${ }^{12}$ Adiwarman A. Karim, Ekonomi Mikro Islami Edisi Kelima (Depok: Rajawali Pers, 2018).

${ }^{13}$ Ahmad Sarwat, Hukum Bermuamalah Dengan Bank Konvensional (Jakarta: Rumah Fiqih Publishing, 2019).
} 
Ahmad Bilal Almagribi, Bayu Taufiq Possumah, Halimi Husayn

Table 2.2 Bank Accounts Held in Indonesia

\begin{tabular}{|c|c|c|}
\hline Types of Banks & $\begin{array}{c}\text { Number of } \\
\text { Respondents }\end{array}$ & Percentage \\
\hline $\begin{array}{c}\text { Do not have a personal account } \\
\text { yet }\end{array}$ & 2 people & $5 \%$ \\
\hline Islamic Banks only & 22 people & $55 \%$ \\
\hline Conventional Banks only & 6 people & $15 \%$ \\
\hline Islamic and Conventional Banks & 10 people & $25 \%$ \\
\hline Total & $\mathbf{4 0}$ people & $\mathbf{1 0 0} \%$ \\
\hline
\end{tabular}

22 students (55\% of respondents) only have an Islamic bank account. 10 students (25\% of respondents) have an account at an Islamic Bank as well as have an account at a Conventional Bank. 6 students (15\%) only have a Conventional Bank account. The remaining 2 students (5\%) have not a bank account yet. This is in line with study that showing most of The National University of Malaysia students deposit their money in banks with Shariah systems. ${ }^{14}$ On the contrary, at the Muhammadiyah Jambi College of Economics, most students still use conventional banks. ${ }^{15}$

Comparing the perceptions that bank interest is usury approved by the bank account ownership above, this study found inconsistentness of some respondents. Among them, 38 students (95\%) were previously stated that bank interest is equal to usury, but they still use conventional banks. It is proven by the table 2.1, that there are 16 students (40\%) who are users of conventional banks. Their reasons to use conventional banks can be found from their perception of the advantages of conventional banks against Sharia banks at the end of this research.

\section{Why You Haven't Created a Bank Account in Indonesia}

The table 2.1 also shows that in this modern era there are still people who do not have a personal bank account, both conventional and Shariah. Both respondents stated that the reason they had not created a bank account was that there was no need and there was no time. When some people bank accounts are very important, can not live without active mobile or internet banking, some others can live without even having a personal account.

\section{The Urgency of Using Sharia Banks}

Many respondents stated that they need to use Sharia Banks for the following reasons: (i) To transact by Islamic law. (ii) Solutions to avoid the sin of usury. (iii) To support Islamic finance development. (iv) Sharia banks are fewer disadvantages. (v) The existence of Wadiah contract where the customer will not get additional when saving money, just like an entrust. (vi) Like the new mualaf converting to Islam, the Muslim community needs to participate and help develop Sharia banks. (vii) The Customer shall be directed to the sharia contracts and away from Gharar. (viii) If there is already a Sharia bank, it is no longer permissible to use conventional banks. (ix) Following a fatwa of Saudi Arabian scholars prohibiting bank interest. (x) Safeguard property from prohibited transactions. (xi)

\footnotetext{
${ }^{14}$ Mohd Arip Kasmo et al., 'The Role of Religious Education in Promoting the Islamic Banking System among the Young Muslim Generation: A Case Study', Journal of Sustainable Development 8, no. 1 (28 January 2015): p194, https://doi.org/10.5539/jsd.v8n1p194.

${ }^{15}$ Wella Sandria, 'Persepsi Mahasiswa Tentang Bank Syariah Terhadap Keputusan Menabung Di Perbankan Syariah’, Jurnal Development 6, no. 2 (27 December 2018): 178-90.
} 
The increasing number of Sharia bank customers, it is expected to reduce the growth of conventional banks (xii) As a form of identity and the special character of Islam in banking. (xiii) A form of concern for Islamic law. (xiv) Using a conventional bank means agreeing to its illicit contracts and supporting them. (xv) Reduce inflation caused by usury transactions.

The monetary crisis in 1998 was a negative impact of usury activities on loan and deposits interest. ${ }^{16}$ Therefore, at the end of 2003 the Indonesian Ulama Council (MUI) issued a fatwa that bank interest is equal to usury and among its points is for existing areas of Islamic financial institutions, it should no longer transactions in conventional institutions. Exceptions are only given for those in the region there are no Islamic financial institutions, even with the principle of emergency. ${ }^{17}$ Financing in a Sharia bank will not be approved if the object of financing is unlawful, inflicting harm to the community, relating to immorality, gambling, the illegal weapons industry, the development of mass murder weapons, and projects that can harm the glory of Islam. ${ }^{18}$ At a minimum, by becoming a Sharia bank user, customers are not involved in helping businesses that are not following Sharia principles.

Other respondents who have the opposite view do not need Sharia banking to argue that (i) Sharia Banks in Indonesia have the same system as conventional. (ii) Some features in Sharia Banks still contain usury elements. (iii) Sharia banks only play in the term of the contract, either in Sharia banks or conventional banks, all interest rates remain illegal. (iv) If the usury system is eliminated there is no need for Sharia banks.

Some other respondents, although still encouraged to use Sharia banks, they also conveyed some criticism about Sharia banks as follows: (i) There is still an element of usury. (ii) The contracts still need to be checked and repaired by the Sharia council. (iii) Still induct into Bank Indonesia (BI) which adheres to the conventional system. (iv) There is a late penalty like usury. (v) Loss sharing has not been implemented. Customers whose businesses fail still must repay the principal loan in full. (vi) The most frequently used financing agreements are still limited to Murabahah contract.

\section{Sharia Banks That Have Been Used and Their Advantages}

There are 5 types of Sharia banks used by the respondents of this study as in table 2.3 below:

Table 2.3 Sharia Banks of Respondents

\begin{tabular}{|c|c|c|}
\hline Bank Name & $\begin{array}{c}\text { Number of } \\
\text { Respondents }\end{array}$ & Percentage \\
\hline BNI Syariah & 21 people & $65,6 \%$ \\
\hline Mandiri Syariah & 7 people & $21,9 \%$ \\
\hline Muamalat & 2 people & $6,3 \%$ \\
\hline BCA Syariah & 1 person & $3,1 \%$ \\
\hline BRI Syariah & 1 person & $3,1 \%$ \\
\hline Total & $\mathbf{3 2}$ people & $\mathbf{1 0 0} \%$ \\
\hline
\end{tabular}

\footnotetext{
${ }^{16}$ Abdul Wahid al-Faizin and Nashr Akbar, Tafsir Ekonomi Kontemporer: Menggali Teori Ekonomi Dari AyatAyat Al-Qur'an (Depok: Gema Insani, 2018).

17 Moh. Mufid, Kaidah FIkih Ekonomi Dan Keuangan Kontemporer: Pendekatan Tematis Dan Praktis (Jakarta: PrenadaMedia Group, 2019).

${ }^{18}$ Muhammad Syafii Antonio, Bank Syariah: Dari Teori Ke Praktik (Jakarta: Gema Insani, 2019).
} 
The table above shows that most respondents were 21 students (65.6\%) out of a total of 32 respondents who have used Sharia banks chose BNI Syariah. Their choice falls on BNI Syariah because (i) cooperates with MasterCard, so it can be used for electronic shopping. (ii) The existence of Wadiah agreement which makes no additions. (iii) ATM that is widely spread. (iv) Mobile banking with many and complete facilities. (v) Deposit and withdraw cash without fee with the same ATM as conventional. (vi) There is no monthly fee.

7 respondents (21.9\%) other uses Bank Mandiri Syariah reasoned because (i) Can deposit money with its conventional bank ATM for free. (ii) Easy to distribute alms and zakat. (iii) Mobile banking facilities are good. (iv) The availability of Wadiah agreement. (v) Many branch offices. Meanwhile, Bank Muamalat was used by 2 respondents (6.3\%) because it is a pioneer of Sharia banks in Indonesia. 1 respondent (3.1\%) use BCA Syariah because there is a Wadiah agreement, good mobile banking, and can withdraw cash at conventional banks. BRI Syariah is used only by 1 person (3.1\%), even because the salary money is sent to this bank.

\section{Disadvantages of Islamic Banks Compared to Conventional}

As sharia bank users, some respondents still found some shortcomings in Islamic banks when compared to conventional banks. The drawbacks include: (i) More expensive financing margins. (ii) There are Islamic banks whose mobile banking is heavy, the features are not as much as conventional banks, even some do not have mobile banking features. (iii) ATM network is still small, especially for Islamic banks whose ATM is different from conventional. (iv) Lack of cooperation with Visa and MasterCard. (v) One of the Sharia banks cannot be used for withdrawal of funds abroad (international). (vi) Digital services for virtual shopping are still less supportive. Indicated by the absence of instant debit cards recognized by the Indonesian marketplace. (vii) There is no Islamic bank debit card that is as valid as a credit card. (viii) The number of branch offices is still limited. (ix) There is no free transfer service to different banks. (x) State regulations that are still not fully able to support Islamic bank operations. For example, it is not permissible to do direct business. (xi) Lack of advertising promotion and socialization.

Respondents' opinion that the margin of financing in Sharia banks is more expensive has been refuted by Ifham that it cannot compare the clear and fixed value of Islamic bank financing with the uncertain credit value of conventional banks. ${ }^{19}$ Because it could be that after all this time customers can not afford to pay with interest that continues to rise, even eventually exceeding the value of Islamic bank financing that at first looks more expensive.

The results of this study are similar to previous studies in which absence or distance of an Islamic bank branch office from residential areas and family factors are the reason students of Al-Azhar Islamic College Gowa, ${ }^{20}$ Kuantan Singingi Islamic University, ${ }^{21}$ and students of the State Islamic Institute of Metro still use conventional banks. ${ }^{22}$ In addition to

\footnotetext{
${ }^{19}$ Ahmad Ifham, Membongkar Rahasia Bank Syariah (Jakarta: PT Gramedia Pustaka Utama, 2016).

${ }^{20}$ Hasriani Hasriani et al., 'Analisis Penerapan Pelarangan Riba Terhadap Mahasiswa STAI Al-Azhar Gowa', Al-Azhar Journal of Islamic Economics 2, no. 1 (2020): 47-52, https://doi.org/10.37146/ajie.v2i1.40.

${ }^{21}$ Meri Yuliani and Dian Meliza, 'Partisipasi Mahasiswa Perbankan Syariah Universitas Islam Kuantan Singingi (UNIKS) Untuk Menabung Di Bank Syariah Teluk Kuantan’, Jurnal Tabarru’: Islamic Banking and Finance 2, no. 2 (15 November 2019): 50-59, https://doi.org/10.25299/jtb.2019.vol2(2).4399.

${ }^{22}$ Retno Juwita Ningrum, 'Faktor Yang Mempengaruhi Mahasiswa S1 Perbankan Syariah IAIN Metro Bertransaksi Dengan Bank Konvensional (Studi Kasus Pada Mahasiswa S1 Perbankan Syariah Angkatan 2015)’ (undergraduate, IAIN Metro, 2019), https://repository.metrouniv.ac.id/id/eprint/651/.
} 
the reason for the location, students of Brawijaya University also reasoned that the costs and facilities provided by Islamic banks are still inferior compared to conventional banks. ${ }^{23}$

\section{CONCLUSION}

Indonesian students in Medina as respondents to this research in their perception of bank interest are divided into two groups. The first group as majority considers bank interest is usury. While the minority, the second group considers usury and conventional bank interest is not the same. Respondents of the first group argued that bank interest is the same as riba stated that the contract between the bank and the customer is a loan contract (Qordh). It refers to the rule of any benefits from the loan is riba. The additional value that must be paid by the customer as a borrower and the interest given by conventional banks to depositors is also a form of usury. Additional value is not based on real business profits, but based on interest rates. In contrast, respondents in the second group argued that between usury and conventional bank interest is different because not all interest is usury. And some scholars have argued that the contract between the customer and the bank is financing (Tamwil), not a loan. Many respondents already have Islamic bank accounts in Indonesia, but some of them still use conventional banks for various reasons such as the limited number of branch offices and ATMs, and the absence of Islamic debit cards that recognized as credit cards in online transactions.

Since this research is limited in reaching Indonesian students in Medina, the other researchers suggested that further research can also be done on the perception of bank interest in other countries. Similarly, research methods can be developed to find out what factors are more significant in making customers career by using Islamic banks or vice versa.

\section{REFERENCES}

'32.-Bunga-InterestFaidah.Pdf'. Accessed 22 December 2020. http://mui.or.id/wpcontent/uploads/files/fatwa/32.-Bunga-InterestFaidah.pdf.

Afandi, Nur, and Ernawati Ernawati. 'Sumber Dana Dan Persepsi Tentang Bunga Bank Oleh Pedagang Muslim (Studi Pedagang Di Pasar Basah Di Kota Kendari Tahun 2015)’. Muqtasid: Jurnal Ekonomi Dan Perbankan Syariah 9, no. 1 (26 June 2018): 70-81. https://doi.org/10.18326/muqtasid.v9i1.70-81.

Antonio, Muhammad Syafii. Bank Syariah: Dari Teori Ke Praktik. Jakarta: Gema Insani, 2019.

Faizin, Abdul Wahid al-, and Nashr Akbar. Tafsir Ekonomi Kontemporer: Menggali Teori Ekonomi Dari Ayat-Ayat Al-Qur'an. Depok: Gema Insani, 2018.

'Fatwa 08-2006_Bunga Bank.Pdf'. Accessed 22 December 2020. http://tarjih.muhammadiyah.or.id/muhfile/tarjih/download/Fatwa\%20082006_Bunga\%20Bank.pdf.

Firdaus, Rahmat. 'Perbedaan Pandangan Fuqaha Ihwal Bunga Bank Dan Riba'. EKONOMIKA SYARIAH: Journal of Economic Studies 3, no. 2 (17 December 2019): 47-60. https://doi.org/10.30983/es.v3i2.2150.

${ }^{23}$ Shofiyah Salsabila Se, 'Faktor-Faktor Yang Mempengaruhi Mahasiswa S1 Ekonomi Islam Tidak Menggunakan Bank Syariah Sebagai Alat Utama Dalam Melakukan Transaksi (Studi Kasus Mahasiswa S1 Feb Universitas Brawijaya Angkatan 2015-2016)', Jurnal Ilmiah Mahasiswa FEB 7, no. 2 (24 July 2019), https://jimfeb.ub.ac.id/index.php/jimfeb/article/view/5913. 
Hasriani, Hasriani, Wa Ode Titisalfia, Ammar Munir, and Ardhina Nur Aflaha. 'Analisis Penerapan Pelarangan Riba Terhadap Mahasiswa STAI Al-Azhar Gowa’. Al-Azhar Journal of Islamic Economics 2, no. 1 (2020): 47-52. https://doi.org/10.37146/ajie.v2i1.40.

Ifham, Ahmad. Membongkar Rahasia Bank Syariah. Jakarta: PT Gramedia Pustaka Utama, 2016.

Irwanti, Mayang. 'Pengaruh Motivasi Menghindari Riba Terhadap Keputusan Menjadi Nasabah Bank Syariah (Studi Kasus Mahasiswa di Fakultas Ekonomi UIN SMH Banten, UNTIRTA, UNIBA, UNSERA)’. Diploma, UIN SMH BANTEN, 2020. http://repository.uinbanten.ac.id/5108/.

Karim, Adiwarman A. Ekonomi Makro Islami Edisi Ketiga. Depok: Rajawali Pers, 2017.

—. Ekonomi Mikro Islami Edisi Kelima. Depok: Rajawali Pers, 2018.

Kasmo, Mohd Arip, Bayu Taufiq Possumah, Mohamad Sabri Haron, Hasnan Kasan, and Aminuddin Bashir. 'The Role of Religious Education in Promoting the Islamic Banking System among the Young Muslim Generation: A Case Study'. Journal of Sustainable Development 8, no. 1 (28 January 2015): p194. https://doi.org/10.5539/jsd.v8n1p194.

Kilau, Permata Hati. 'Pengaruh Pemahaman Mahasiswa Perbankan Syariah Atas Bunga Dan Bagi Hasil Terhadap Minat Menjadi Nasabah Bank Syariah (Studi Kasus Mahasiswa Perbankan Syariah IAIN Purwokerto Angkatan 2016-2019)'. Skripsi, IAIN Purwokerto, 2020. http://repository.iainpurwokerto.ac.id/8649/.

Mufid, Moh. Kaidah FIkih Ekonomi Dan Keuangan Kontemporer: Pendekatan Tematis Dan Praktis. Jakarta: PrenadaMedia Group, 2019.

Ningrum, Retno Juwita. 'Faktor Yang Mempengaruhi Mahasiswa S1 Perbankan Syariah IAIN Metro Bertransaksi Dengan Bank Konvensional (Studi Kasus Pada Mahasiswa S1 Perbankan Syariah Angkatan 2015)’. Undergraduate, IAIN Metro, 2019. https://repository.metrouniv.ac.id/id/eprint/651/.

Putra, Rizky Dwi. 'Analisis Pengaruh Pengetahuan Riba Dan Sikap Kepada Bank Syariah Terhadap Intensi Menjadi Nasabah Bank Syariah (Studi Kasus Pada Mahasiswa STIE Indonesia Banking School)’. Diploma, STIE Indonesia Banking School, 2019. http://lib.ibs.ac.id/index.php?p=show_detail\&id=4457\&keywords=RIZKY+DWIP UTRA.

Rahmawaty, Anita. 'Pengaruh Persepsi Tentang Bank Syariah Terhadap Minat Menggunakan Produk di BNI Syariah Semarang'. ADDIN 8, no. 1 (15 November 2015). https://doi.org/10.21043/addin.v8i1.587.

Sandria, Wella. 'Persepsi Mahasiswa Tentang Bank Syariah Terhadap Keputusan Menabung Di Perbankan Syariah’. Jurnal Development 6, no. 2 (27 December 2018): 178-90.

Sarwat, Ahmad. Hukum Bermuamalah Dengan Bank Konvensional. Jakarta: Rumah Fiqih Publishing, 2019.

Se, Shofiyah Salsabila. 'Faktor-Faktor Yang Mempengaruhi Mahasiswa S1 Ekonomi Islam Tidak Menggunakan Bank Syariah Sebagai Alat Utama Dalam Melakukan Transaksi (Studi Kasus Mahasiswa S1 Feb Universitas Brawijaya Angkatan 2015-2016)'. Jurnal Ilmiah Mahasiswa FEB 7, no. 2 (24 July 2019). https://jimfeb.ub.ac.id/index.php/jimfeb/article/view/5913. 
Susanti, Neila, and Marliyah Marliyah. 'Pola Pemberdayaan Ekonomi Generasi Milenial Komunitas Serikat Saudagar Nusantara (SSN)’. Lainnya. Medan: LP2M UIN Sumatera Utara Medan, October 2018. http://repository.uinsu.ac.id/5102/.

Syam, Anggeryani. 'Pengaruh Pemahaman Riba Terhadap Minat Menabung Di Bank Konvensional (Studi Mahasiswa Prodi Perbankan Syariah IAIN Parepare'. Undergraduate, IAIN Parepare, 2019. http://repository.iainpare.ac.id/627/.

Veronica, Vera. 'Pengaruh Fatwa Majelis Ulama Indonesia (MUI) Tentang Bunga Bank Terhadap Motivasi Mahasiswa Program Studi Ekonomi Syariah Di Stai Tasikmalaya Menjadi Nasabah Bank Syariah’. Diploma, STAI Tasikmalaya, 2018. http://repository.staitasik.ac.id:86/25/.

Yuliani, Meri, and Dian Meliza. 'Partisipasi Mahasiswa Perbankan Syariah Universitas Islam Kuantan Singingi (UNIKS) Untuk Menabung Di Bank Syariah Teluk Kuantan'. Jurnal Tabarru': Islamic Banking and Finance 2, no. 2 (15 November 2019): 50-59. https://doi.org/10.25299/jtb.2019.vol2(2).4399. 